\title{
Changes in Forage Quantity and Quality With Continued Late-Summer Cattle Grazing a Riparian Pasture in Eastern Oregon of United States
}

\author{
Enkhjargal Darambazar ${ }^{1}$, Timothy DelCurto ${ }^{2}, \&$ Daalkhaijav Damiran ${ }^{1,3}$ \\ ${ }^{1}$ Western Beef Development Centre, Humboldt, Saskatchewan, Canada \\ ${ }^{2}$ Eastern Oregon Agricultural Research Center, Oregon State University, Union, Oregon, USA \\ ${ }^{3}$ Department of Animal and Poultry Science, University of Saskatchewan, Saskatoon, Saskatchewan, Canada \\ Correspondence: Daalkhaijav Damiran, University of Saskatchewan, Saskatoon, SK, S7H 4R6, Canada. Tel: \\ 1-306-966-4173. E-mail: daal.damiran@usask.ca
}

Received: April 15, 2013 Accepted: August 18, 2013 Online Published: August 20, 2013

doi:10.5539/sar.v2n4p64 URL: http://dx.doi.org/10.5539/sar.v2n4p64

\begin{abstract}
A pasture (45 ha) in northeastern Oregon was grazed with 30 yearlings $(419 \mathrm{~kg}$, Body Condition Score $[\mathrm{BCS}]=$ $5.05)$ and 30 mature cows with calves $(499 \mathrm{~kg}, \mathrm{BCS}=4.65)$ during August of 2001 and 2002. Sampling dates were $\mathrm{d} 0, \mathrm{~d} 10, \mathrm{~d} \mathrm{20}$, and $\mathrm{d} 30$. Forage availability before grazing was $1,039.0 \mathrm{~kg} \cdot \mathrm{ha}^{-1}$ and declined to 332.6 $\mathrm{kg} \cdot \mathrm{ha}^{-1}$ after grazing $(p<0.10)$. Grasses dominated the pasture $(44.5 \%)$, followed by forbs $(30.7 \%)$, grasslikes (15.9\%), and shrubs (8.9\%). Due to grazing quackgrass (Agropyron repens (L.) Beauv.), western fescue (Festuca occidentalis Walt.), California brome (Bromus carinatus Hook.), and redtop (Agrostis alba L.) exhibited the greatest decline in quantity. Shrub utilization was high from d 20 to d 30 (49 to 58\% for willow [Salix rigida \{Hook.\} Cronq.] and 58 to $74 \%$ for alder [Alnus incana \{L.\} Moench.]). Forbs decreased $(p<0.10)$ in moisture late in the grazing period, while shrubs were $(p>0.10)$ still succulent $(63 \%)$. Forbs and shrubs were higher $(p<$ $0.10)$ than grasses in crude protein $(11,14$, and $6 \%$, respectively) and digestibility $(59,50$, and $42 \%$, respectively). In summary, our results suggest that cattle grazing late-summer riparian pastures will switch to intensive shrub utilization when grasses decline in quantity and quality, and forbs decline in quantity. Land managers need to know the effect of their management on vegetation and if a goal is to protect riparian woody vegetation, our data suggest that late-summer grazing should be light, or avoided when grasses have senesced.
\end{abstract}

Keywords: browse, cow, herbage, riparian area management, sustainable grazing

\section{Introduction}

Moist mountain meadows on forested summer range in eastern Oregon and eastern Washington comprise only $1 \%-2 \%$ of the area however, they may produce upwards of $20 \%$ of summer range forage (Reid \& Pickford, 1946). Grazing animals have long been associated with alteration of productivity, cover, and species composition of plant communities (Stoddart et al., 1975; Leege, Herman, \& Zamora, 1981). One of the grazing strategies used to utilize the riparian forage resource, while preserving the integrity of the riparian/stream ecosystem is a late-season grazing strategy (Kauffman, Krueger, \& Vavra, 1983a). Although, as DelCurto et al. (1990) noted late-season distribution problems may exist, which likely related to dormant, senesced upslope vegetation being of lower nutritional value than moist green vegetation available in riparian areas. Moreover, researchers have indicated that wildlife and livestock concentrate riparian areas, creating a substantial impact on browse and herbaceous vegetation (Roath \& Krueger, 1982; DelCurto, Porath, Parsons, \& Morrison, 2005). But as these researchers pointed out, the impact of grazing on riparian shrubs and herbaceous vegetation can be difficult to assess because information on their response to summer utilization is lacking or sparse. Therefore, information on variations in the quantity and quality of available herbage, as well as a better understanding of what drives cattle shift their diets will be important to sustainable and productive use of riparian areas. The objective of this study was to determine changes in herbage quantity, quality, species composition, and shrub utilization in riparian areas over a late summer grazing period. 


\section{Materials and Methods}

\subsection{Study Site}

The study was conducted on the Hall Ranch of the Eastern Oregon Agricultural Research Center, $15 \mathrm{~km}$ southeast of Union, Oregon. The study area consisted of a pasture, 45 ha in size, located along $2.6 \mathrm{~km}$ of Catherine Creek, and is confined by steep hills on the east side and a state highway on the west. Mean annual precipitation for the study area is $60.4 \mathrm{~cm}$, with the majority falling between November and May. Elevation of the study area averages $1,018 \mathrm{~m}$. (Ballard \& Krueger, 2005). Average July and August rainfall, as reported by Porath et al. (2002), totals $3.94 \mathrm{~cm}$. Historically, the riparian pasture along Catherine Creek was grazed heavily under a season long grazing regime (Laliberte, Johnson, Harris, \& Casady, 2001; Ballard \& Krueger, 2005). In 1978, five exclosures (49 ha) were constructed that alternate with grazed portions ( $45 \mathrm{ha}$ ) in the study area. Since 1979, the area had been grazed for 3-4 weeks in the fall to a utilization level of $70 \%$, and a stubble height of 5-cm on Kentucky bluegrass (Kauffman, Krueger, \& Vavra, 1983b; Laliberte et al., 2001; Ballard \& Krueger, 2005). The downstream portion of the study area consisted of an open grassland, while the upper portion contained more shrubs and trees (Laliberte et al., 2001). The ten most widely occurring communities in the riparian zone by Kauffman et al. (1983a) were dry meadow (Poa pratensis-mixed forbs); moist meadow (Poa pratensis-Phleum pratense-Carex spp. and forbs); Kentucky bluegrass-cheatgrass (Poa pratensis-Bromus tectorum); Douglas hawthorne/Kentucky bluegrass (Crataegus douglasii/Poa pratensis); snowberry-woods rose (Symphoricarpos albus-Rosa woodsii); gravel bars (Salix spp-Populus trichocarpa sapling-mixed graminoids-mixed forbs); thinleaf alder/Kentucky bluegrass (Alnus incana/Poa pratensis); ponderosa pine/Kentucky bluegrass (Pinus ponderosa/Poa pratensis); and black cottonwood-mixed conifer (Populus trichocarpa-mixed conifer).

The study was conducted as a completely random design with repeated measures. The pasture was grazed by sixty head of cattle consisting of thirty yearling heifers $(419 \mathrm{~kg}$, Body Condition Score $(\mathrm{BCS})=5.05)$ and thirty mature cows $(499 \mathrm{~kg}, \mathrm{BCS}=4.65)$ with calves. The grazing was initiated 7 August and ended 7 September in 2001 (Year 1), but started 31 July and ended 31 August in 2002 (Year 2) due to drought conditions. In Year 2, mature cows from Year 1 that were still in the herd and within the age requirements were used again. A new group of yearling heifers were used each year. Data collected at 10-day intervals during a 30-day grazing trial (d $0, \mathrm{~d} 10, \mathrm{~d} 20$, and $\mathrm{d} 30$ ), included herbage production by species, moisture content and nutritive quality of the major forage species, and shrub utilization.

\subsection{Herbage Production of Forage}

We monitored herbaceous production of the riparian pasture for 2 consecutive years during 2001 and 2002 . Standing crop of total herbage by species at 10-day intervals was estimated to evaluate the changes in forage quantity during the 30-day grazing period. On each sampling date, $50,0.25-\mathrm{m}^{2}$ circular plots were placed every $30 \mathrm{~m}$ along five permanent transects across the pasture and clipped to determine standing crop by species. This resulted in a total of 200 sampling plots in each of the 2 years of the study. We separated current year's crop from total standing crop to quantify year effects to annual productivity. Current year's standing crop was clipped to ground level, separated into live and dead materials, the latter of which was discarded. Live material (standing crop) was further separated by species, oven dried at $60^{\circ} \mathrm{C}$, and weighed. Total standing crop was determined as a sum of the weight of each species in a plot, expressed in $\mathrm{kg} \cdot \mathrm{ha}^{-1}$. Utilization (herbage disappearance) was estimated by subtracting residual forage from herbage standing crop before grazing. Data by species were placed into functional groups based on plant growth form. Plant species nomenclature and separating plants by growth form throughout this paper follow Hitchcock, Cronquist, Ownbey, and Thompson (1969).

\subsection{Sampling for Nutritive Analysis}

Fourteen major forage species ( 6 grasses, 1 sedge, 4 forbs, and 3 shrubs) were sampled to evaluate the change in forage nutritive quality in the pasture. For each plant species, a composite sample of approximately $40 \mathrm{~g}$ (dry weight) was collected throughout the study area at each sampling date through hand plucking to simulate grazing (Darambazar, 2003).

\subsection{Moisture Content and Nutritive Analysis}

The hand plucked samples of the major forage species were weighed, oven-dried at $60{ }^{\circ} \mathrm{C}$, and reweighed to determine moisture content. After grinding through a $1 \mathrm{~mm}$ screen (Wiley Mill, Model 4, Arthur H. Tomas Co., Philadelphia, PA, USA), the samples were analyzed for ash (AOAC method \# 942.05), crude protein (CP) content determined by the Kjeldahl procedure using a Kjeltec Auto System (Kjeltec Auto System, Büchi, Flawil, Switzerland) (AOAC method \# 984.13), and in vitro dry matter and organic matter digestibilities (IVDMD and 
IVOMD) by Tilley and Terry (1963) technique. Acid detergent fiber (ADF) and neutral detergent fiber (NDF) with heat stable $\alpha$-amylase were analyzed according to the procedures of Van Soest, Robertson, and Lewis (1991) using an ANKOM Fiber Analyzer (ANKOM Technology Corporation, Fairport, NY). All data on nutritive quality are reported on a dry matter (DM) basis.

\subsection{Shrub Utilization}

Shrub utilization was evaluated by the photographic technique (Damiran, DelCurto, Johnson, Findholt, \& Johnson, 2006) at each sampling date. Sixteen individual shrubs of two shrub species (8 firmleaf willows [Salix rigida \{Hook.\} Cronq.] and 8 thinleaf alders [Alnus incana $\{$ L.\} Moench.]) were selected randomly across the study site. The photos of the shrubs were taken with a digital camera and images were evaluated using image-processing software. Shrub utilization was estimated by calculating reduction in green leaf area size, expressed in $\mathrm{cm}^{2}$. Utilization estimated as percentage of green leaf area was calculated as follows: Utilization (\%) $=\left(\right.$ Before browsing leaf area size $\mathrm{cm}^{2}-$ After browsing leaf area size, $\left.\mathrm{cm}^{2}\right) /($ Before browsing leaf area size, $\left.\mathrm{cm}^{2}\right) \times(100)($ Damiran et al., 2006).

\subsection{Statistical Analysis}

Data were analyzed using PROC mixed procedure of SAS (2001). Time series data were analyzed as a repeated measures design. Means were separated using least square means procedure and were considered different at the $(p<0.10)$ level.

\section{Results and Discussion}

\subsection{Precipitation}

Total annual precipitation for the study years was $27.2 \mathrm{~cm}$ in 2001 and $30.6 \mathrm{~cm}$ in 2002, which was 55 and $49 \%$ below average for the area, respectively (Figure 1). Also, the August period was drier than typical for the northeastern part of Oregon during the study years. Measured amount of precipitation received during the study periods (around the month of August) was $1.0 \mathrm{~cm}$ in Year 1 and $1.3 \mathrm{~cm}$ in Year 2, which was 50 and 35\% less than average for August for the area, respectively. Average daily temperatures for this time were recorded at 20.1 ${ }^{\circ} \mathrm{C}$ in Year 1 and $19.6{ }^{\circ} \mathrm{C}$ in Year 2. Precipitation and temperature data were measured at the Union, Oregon weather station located northwest $(<20 \mathrm{~km})$ of the study site (Darambazar, 2003).

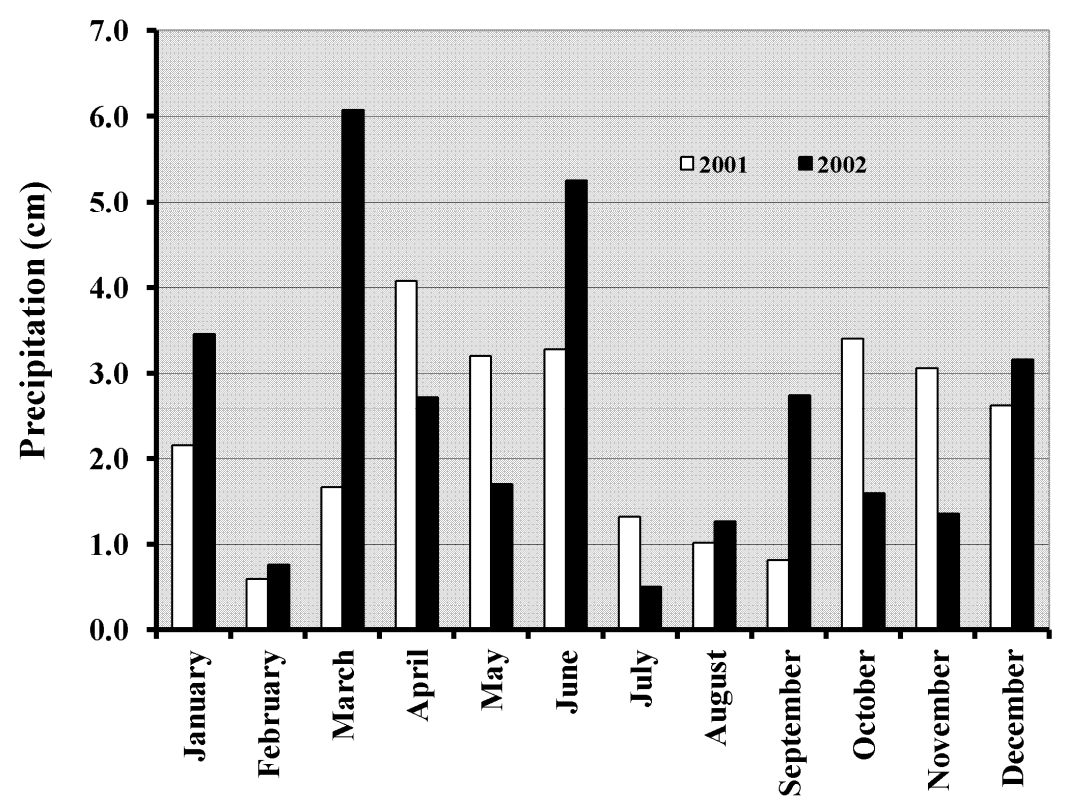

Figure 1. Annual monthly precipitation during the study years of 2001 and 2002 measured at the Oregon State

University's Eastern Oregon Agriculture Research Center in Union, Oregon, USA

\subsection{Herbage Production of Forage}

Total of 77 to 82 vascular plant species was recorded and identified on the pasture during the period of the study years. Plant species encountered in $0.25 \mathrm{~m}^{2}$ ranged from 1 to 17 , averaging 7 species per plot on $\mathrm{d} 0$. This 
number however, declined to $6(p<0.10)$ later in the grazing period.

Herbage standing crop in the pasture did not vary $(p>0.10)$ between years and averaged $1,039.0 \mathrm{~kg}^{\circ} \mathrm{ha}^{-1}$ before grazing, but declined $(p<0.10)$ continuously throughout the grazing period to $332.6 \mathrm{~kg} \cdot \mathrm{ha}^{-1}$ after grazing (Figure 2). By comparison, the standing crop of herbage in August on continuously grazed plots in north-central Oregon determined by Gillen, Krueger, \& Miller (1985) was $1,200 \mathrm{~kg}^{\cdot h a^{-1}}$, while Parsons, Momont, DelCurto, McInnis, Porath (2003) estimated forage availability in northeastern Oregon during late- season grazing (mid-August to mid-September) to be $1,726 \mathrm{~kg}^{\cdot \mathrm{ha}^{-1}}$. The estimated value of standing crop of total herbage in our study was below these values, which could be attributed to the drought conditions experienced in the summers of the study years. Cattle seem to have used the pasture vigorously from the onset of the grazing period, which was indicated by removal of $28.8 \%$ of herbage by d 10 . Although the removal rate was lower (18 to $21 \%$ ) later in the season, utilization levels of available forage increased reaching highs of 49.6 to $68.0 \%$. Our findings generally, agreed with those found in northeastern Oregon by Buckhouse, Skovlin, and Knight (1981) and Kauffman et al. (1983b) where utilization of streamside vegetation was 65 to $70 \%$ and $59 \%$ (ranged from 35 to $85 \%$ ), respectively in the areas grazed by cattle and also with agreement with $57 \%$ in the moist year and $74 \%$ in the drier year recorded by Ballard and Krueger (2005). At the initiation of grazing, grasses were the most abundant forage $(44.6 \%)(p<$ $0.10)$, forbs were the next most abundant (30.6\%), with grasslikes $(16.0 \%)$ and shrubs $(8.9 \%)$ making up lesser portions of the available herbage (Table 1). As the season progressed, grasses and forbs substantially decreased in herbage mass $(p<0.10)$, only the latter declining less severely at the end of the grazing $(p>0.10)$. Cattle utilized grasslikes gradually with similar amounts being removed $(p>0.10)$ over the 10-day intervals, although this resulted in significant herbage disappearance for this forage at the end of the grazing period $(p<0.10)$. Production of woody vegetation did not change on this pasture during the grazing period $(p>0.10)$.

Table 1. Standing crop of forages $\left(\mathrm{kg} \mathrm{ha}^{-1}\right)$ and utilization (\%) in late-summer grazing season in the Catherine Creek riparian area on the Hall Ranch in northeastern Oregon USA

\begin{tabular}{llcccc}
\hline \multirow{2}{*}{ Forages } & \multicolumn{5}{c}{ Dates* $^{*}$} \\
\cline { 2 - 6 } Grasses & Standing crop & $470.5^{\mathrm{a}}$ & $353.5^{\mathrm{b}}$ & $266.5^{\mathrm{c}}$ & $176.9^{\mathrm{d}}$ \\
& Utilization & & 24.9 & $43.4^{\mathrm{a}}$ & 62.4 \\
Grasslike & Standing crop & $168.4^{\mathrm{a}}$ & $115.5^{\mathrm{a}}$ & $83.9^{\mathrm{ab}}$ & $69.9^{\mathrm{b}}$ \\
& Utilization & & 31.4 & 50.2 & 58.5 \\
\multirow{3}{*}{ Forbs } & Standing crop & $325.2^{\mathrm{a}}$ & $168.4^{\mathrm{b}}$ & $89.3^{\mathrm{c}}$ & $51.0^{\mathrm{c}}$ \\
& Utilization & & 48.2 & 72.5 & 84.3 \\
Shrubs & Standing crop & $93.6^{\mathrm{a}}$ & $92.2^{\mathrm{a}}$ & $78.1^{\mathrm{ab}}$ & $25.6^{\mathrm{b}}$ \\
& Utilization & & 0.1 & 16.6 & 72.6 \\
\hline
\end{tabular}

* Row values with different superscripts differ $(p<0.10$; se $=28.67 ; n=100)$. 


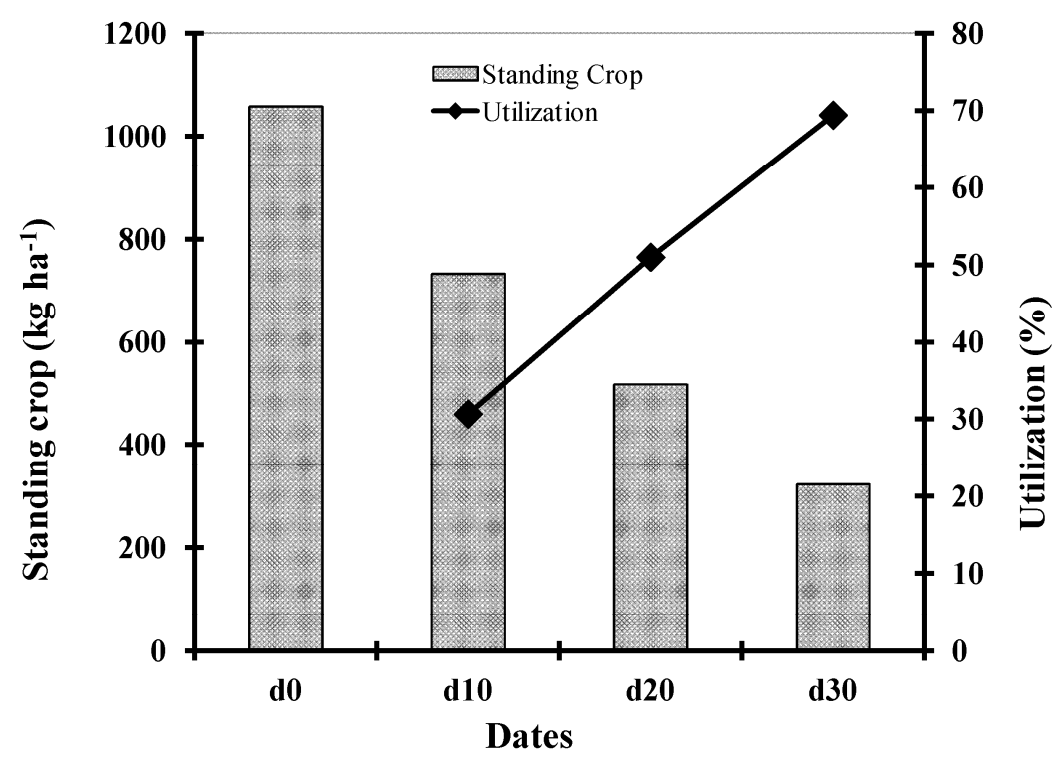

Figure 2. Standing crop of total herbage $\left(\mathrm{kg} \cdot \mathrm{ha}^{-1}\right)$ and utilization (\%) in late-summer grazing season in the Catherine Creek riparian area on the Hall Ranch in northeastern Oregon USA $\left({ }^{\mathrm{a}, \mathrm{b}, \mathrm{c}, \mathrm{d}}\right.$ Values with different superscripts differ. $p<0.05$; $\mathrm{se}=63.61 ; n=100$ )

Overall, all forages received heavy utilization, over $50 \%$ at the end of the grazing period with the highest being found for forbs, shrubs were the next greatest, and grasses and grasslikes were at similar utilization levels and accounting for the least disappearing forages. Kentucky bluegrass (Poa pratensis L.) comprised almost 11\% of the total herbage and was the major portion of the available forage. Timothy (Phleum pratense L.) and sedges (Carex spp.) were the next most important forage components making up 9.4 and $7.8 \%$, respectively (Table 2). The highest percent disappearances (84 to 93\%) were found in quackgrass (Agropyron repens (L.) Beauv.), western fescue (Festuca occidentalis Walt.), California brome (Bromus carinatus Hook.), and redtop (Agrostis alba L.), although initially their availability did not exceed $5 \%$ of the total herbage.

Table 2. Standing crop of the major forage species $\left(\mathrm{kg} \mathrm{ha}^{-1}\right)$ and utilization (\%) in late-summer grazing season in the Catherine Creek riparian area on the Hall Ranch in northeastern Oregon USA

\begin{tabular}{lcccccccc}
\hline & \multicolumn{4}{c}{ Standing Crop* $\left(\mathrm{kg} \cdot \mathrm{ha}^{-1}\right)$} & \multicolumn{3}{c}{ Utilization (\%) } \\
\hline Forage Species & $\mathrm{d} 0$ & $\mathrm{~d} \mathrm{10}$ & $\mathrm{d} 20$ & $\mathrm{~d} 30$ & $\mathrm{se} \dagger$ & $\mathrm{d} 10$ & $\mathrm{~d} 20$ & $\mathrm{~d} 30$ \\
Kentucky Bluegrass & $115.6^{\mathrm{a}}$ & $103.0^{\mathrm{a}}$ & $89.3^{\mathrm{ab}}$ & $55.2^{\mathrm{b}}$ & 16.23 & 10.9 & 22.8 & 52.2 \\
Timothy & $99.2^{\mathrm{a}}$ & $59.9^{\mathrm{ab}}$ & $50.6^{\mathrm{b}}$ & $27.1^{\mathrm{b}}$ & 19.41 & 39.6 & 49 & 72.7 \\
Redtop & $48.8^{\mathrm{a}}$ & $21.4^{\mathrm{b}}$ & $18.2^{\mathrm{b}}$ & $8.0^{\mathrm{b}}$ & 8.44 & 56 & 62.6 & 83.7 \\
Quackgrass & $36.6^{\mathrm{a}}$ & $12.4^{\mathrm{b}}$ & $4.8^{\mathrm{b}}$ & $2.7^{\mathrm{b}}$ & 9.92 & 66.1 & 86.9 & 92.7 \\
Western Fescue & $33.0^{\mathrm{a}}$ & $32.7^{\mathrm{a}}$ & $19.9^{\mathrm{a}}$ & $3.4^{\mathrm{a}}$ & 17.64 & 0.1 & 39.6 & 89.8 \\
California Brome & $12.5^{\mathrm{a}}$ & $3.2^{\mathrm{b}}$ & $1.6^{\mathrm{b}}$ & $2.0^{\mathrm{b}}$ & 3.67 & 74 & 87.3 & 84.3 \\
Sedges & $82.6^{\mathrm{a}}$ & $51.8^{\mathrm{ab}}$ & $43.3^{\mathrm{ab}}$ & $30.7^{\mathrm{b}}$ & 20.63 & 37.4 & 47.7 & 62.8 \\
Red Clover & $61.1^{\mathrm{a}}$ & $14.5^{\mathrm{b}}$ & $13.8^{\mathrm{b}}$ & $6.3^{\mathrm{b}}$ & 13.82 & 76.2 & 77.4 & 89.7 \\
Western Yarrow & $34.3^{\mathrm{a}}$ & $28.0^{\mathrm{ab}}$ & $17.9^{\mathrm{ab}}$ & $14.3^{\mathrm{b}}$ & 3.84 & 18.3 & 47.6 & 58.3 \\
Heartleaf Arnica & $13.4^{\mathrm{a}}$ & $7.1^{\mathrm{ab}}$ & $2.9^{\mathrm{a}}$ & $2.0^{\mathrm{b}}$ & 8.12 & 47.1 & 78.2 & 85.1 \\
Strawberries $\ddagger$ & $7.3^{\mathrm{a}}$ & $6.9^{\mathrm{a}}$ & $5.5^{\mathrm{ab}}$ & $2.1^{\mathrm{b}}$ & 1.76 & 0.1 & 24.1 & 70.8 \\
Common Snowberry & $81.5^{\mathrm{a}}$ & $93.7^{\mathrm{a}}$ & $73.4^{\mathrm{a}}$ & $23.2^{\mathrm{b}}$ & 15.18 & -14.9 & 10 & 71.5 \\
\hline
\end{tabular}

* Row values within each species with different superscripts differ $(p<0.10 ; n=100)$.

$\dagger$ Standard error of mean. 
\pm Strawberries included two species: blueleaf strawberry (Fragaria virginiana Duchsne) and woods strawberry (Fragaria vesca L.).

In addition to herbage removal by cattle, advancing maturity and (or) senescence due to drought have contributed to the extensive disappearing for these species. In our study, Kentucky bluegrass, the most abundant forage, was utilized at 52\%, which was the lowest among the forages. Hurd and Pond (1958) have implied that utilization of a species did not appear to be influenced by frequency, abundance, or amount of herbage produced. Timothy and sedges were utilized at 63 and $73 \%$, respectively. Our findings were lower or within the range of those estimated by Kauffman et al. (1983a), where Kentucky bluegrass utilization in moist meadow community was 67 to $80 \%$, timothy was utilized at 60 to $76 \%$, and sedges were utilized at 65 to $81 \%$. Red clover (Trifolium pratense $\mathrm{L}$.) and western yarrow (Achillea millefolium var. lanulosa $\mathrm{L}$.) were the primary forb components in the herbage mass. The most utilized forb species were red clover and heartleaf arnica (Arnica cordifolia Hook.) with 85.1 and $89.7 \%$, respectively, while utilization of western yarrow was $58.3 \%$ at the end of the grazing period. Holechek, Vavra, Skovlin, and Krueger (1982) noted that western yarrow and heartleaf arnica were utilized throughout the grazing period because both species remained green and succulent until October in most years. In our study, common snowberry (Symphoricarpos albus [L.] Blake.) was an important shrub component making up $7.7 \%$ of the total forage and its utilization reached high: $72 \%$ at the end of the grazing season. Similarly, Holechek et al. (1982) observed cattle grazing particularly common snowberry, probably because the leaves were still green and succulent.

\subsection{Moisture Content of Forages}

In an attempt to determine the succulence of forages as the season advances, we estimated that water content of forage declined from 63.2 to $51.1 \%(p<0.10)$ during the late summer, but the rate of decline was strongly influenced by forage type (Table 3). Specifically, forbs declined in moisture gradually throughout the grazing period with a notable decrease from the initial level (by 14.5\%) being found late in the season $(p<0.10)$. In contrast, a sharper, (averaged 17.8\%) and earlier (starting from d 20) decrease in moisture was observed for grasses and grasslikes $(p<0.10)$. Shrubs, meanwhile, did not change in moisture over the grazing period containing an average $62.8 \%(p>0.10)$. DelCurto et al. (2005) noted that moisture content or greenness of forage can influence the duration and timing of cattle grazing certain forage. In a study in the Big Horn Basin of northcentral Wyoming, Smith, Rodgers, Dodd, and Skinner (1992) determined the proportion of dry matter (succulence) of forages in channel/floodplain community being 44.7 to $49.3 \%$ from late-July to mid-August. Our findings generally concur with Svejcar and Vavra (1985) and Parsons et al. (2003) where on unimproved rangelands forbs senesced quickly and provided essentially no forage for herbivores during mid to late-summer and dry matter of the forages increased from $43 \%$ in early season to $68 \%$ in late season. At individual species level, redtop had relatively high (58\%) but western fescue relatively low initial moisture (42.2\%) among grasses, and the latter together with California brome (51.2\%) declined in moisture dramatically to less than $30 \%$ by the end of the season (Table 3). Our results indicated that the most succulent forage species were red clover and heartleaf arnica, the latter possessing from 79 to $75 \%$ moisture during the season. Concurrently, Pickford \& Reid (1948) noted that heartleaf arnica is a better forage plant perhaps because it retains moisture longer and does not senesce quickly compared to other forage plants. In contrast, western yarrow demonstrated a strong sign of senescence among forbs, dropping by almost $30 \%$ from its initial moisture content of $66.4 \%$. Although shrub species had similar moisture contents during the trials, thinleaf alder possessed the highest among them, averaging $63.5 \%$. 
Table 3. Moisture content (\%) of forages and the major forage species in late-summer grazing season in the Catherine Creek riparian area on the Hall Ranch in northeastern Oregon, USA

\begin{tabular}{|c|c|c|c|c|c|}
\hline & & & Dates* & & \\
\hline Forages \& Forage Species & $\mathrm{d} 0$ & d 10 & $\mathrm{~d} 20$ & d 30 & $\mathrm{se}^{\dagger}$ \\
\hline Grasses \& Grasslike & $52.2^{\mathrm{a}}$ & $48.5^{\mathrm{a}}$ & $33.5^{\mathrm{b}}$ & $33.8^{\mathrm{b}}$ & 2.52 \\
\hline California Brome & $51.2 \pm 6.8$ & $40.6 \pm 7.2$ & $23.0 \pm 5.9$ & $24.3 \pm 5.8$ & \\
\hline Kentucky Bluegrass & $54.8 \pm 3.4$ & $53.8 \pm 7.6$ & $38.7 \pm 7.4$ & $36.6 \pm 5.6$ & \\
\hline Quackgrass & $52.1 \pm 1.0$ & $51.1 \pm 5.8$ & $32.7 \pm 4.8$ & $37.4 \pm 2.1$ & \\
\hline Redtop & $58.2 \pm 1.4$ & $60.4 \pm 6.4$ & $45.4 \pm 3.6$ & $44.0 \pm 1.0$ & \\
\hline Elk Sedge & $51.1 \pm 4.9$ & $50.4 \pm 7.0$ & $35.6 \pm 1.0$ & $34.9 \pm 6.6$ & \\
\hline Timothy & $55.9 \pm 2.4$ & $46.4 \pm 4.1$ & $33.8 \pm 5.9$ & $33.2 \pm 6.5$ & \\
\hline Western Fescue & $42.2 \pm 0.4$ & $36.8 \pm 5.4$ & $25.5 \pm 8.2$ & $26.5 \pm 4.2$ & \\
\hline Forbs & $72.0^{\mathrm{a}}$ & $70.8^{\mathrm{a}}$ & $63.5^{\mathrm{ab}}$ & $59.5^{\mathrm{b}}$ & 3.33 \\
\hline Heartleaf Arnica & $78.7 \pm 1.5$ & $77.1 \pm 2.3$ & $75.3 \pm 0.8$ & $74.6 \pm 1.7$ & \\
\hline Red Clover & $73.9 \pm 0.5$ & $74.9 \pm 1.8$ & $69.9 \pm 1.0$ & $70.0 \pm 1.3$ & \\
\hline Strawberries $\S$ & $69.2 \pm 4.6$ & $65.3 \pm 8.3$ & $56.7 \pm 3.1$ & $56.6 \pm 2.5$ & \\
\hline Western Yarrow & $66.4 \pm 2.7$ & $65.8 \pm 1.0$ & $52.1 \pm 1.2$ & $36.9 \pm 3.4$ & \\
\hline Shrubs & $65.4^{\mathrm{a}}$ & $63.2^{\mathrm{a}}$ & $61.1^{\mathrm{a}}$ & $60.9^{\mathrm{a}}$ & 3.81 \\
\hline Thinleaf Alder & $68.5 \pm 0.1$ & $63.6 \pm 0.2$ & $61.5 \pm 2.8$ & $60.2 \pm 2.3$ & \\
\hline Common Snowberry & $63.3 \pm 0.9$ & $62.2 \pm 0.4$ & $60.1 \pm 0.9$ & $61.7 \pm 0.4$ & \\
\hline Firmleaf Willow & $64.4 \pm 1.7$ & $63.7 \pm 0.3$ & $61.8 \pm 1.0$ & $60.9 \pm 0.9$ & \\
\hline
\end{tabular}

* Values of forages with different superscripts differ $(p<0.10 ; n=14,8$, and 6$)$.

$\uparrow$ Standard error of mean.

$\$$ Forage species' data averaged ( \pm se) over 2 years.

$\S$ Strawberries included two species: blueleaf strawberry and woods strawberry.

Table 4. Chemical composition and digestibility of grasses in late-summer grazing season in the Catherine Creek riparian area on the Hall Ranch in northeastern Oregon USA for 2001 and 2002

\begin{tabular}{lccccccccc}
\hline \multicolumn{1}{c}{2001} & 2002 \\
\hline Item* & $\mathrm{d} 0$ & $\mathrm{~d} 10$ & $\mathrm{~d} 20$ & $\mathrm{~d} 30$ & $\mathrm{~d} 0$ & $\mathrm{~d} 10$ & $\mathrm{~d} 20$ & $\mathrm{~d} 30$ & $\mathrm{se} \dagger$ \\
$\mathrm{CP}$ & $5.3^{\mathrm{a}}$ & $4.9^{\mathrm{a}}$ & $3.9^{\mathrm{a}}$ & $4.0^{\mathrm{a}}$ & $9.7^{\mathrm{a}}$ & $5.7^{\mathrm{b}}$ & $6.1^{\mathrm{b}}$ & $7.8^{\mathrm{b}}$ & 0.79 \\
$\mathrm{NDF}$ & $63.9^{\mathrm{a}}$ & $68.0^{\mathrm{a}}$ & $70.0^{\mathrm{b}}$ & $70.8^{\mathrm{b}}$ & $68.4^{\mathrm{a}}$ & $64.7^{\mathrm{a}}$ & $61.4^{\mathrm{b}}$ & $62.7^{\mathrm{b}}$ & 2.12 \\
\multicolumn{8}{c}{ Digestibility (\%) } \\
IVDMD & 43.2 & 40.2 & 38.6 & 37.8 & $39.3^{\mathrm{a}}$ & $43.0^{\mathrm{a}}$ & $46.2^{\mathrm{b}}$ & $47.5^{\mathrm{b}}$ & 2.14 \\
IVOMD & 43.3 & 40.3 & 38.6 & 37.8 & $39.7^{\mathrm{a}}$ & $43.0^{\mathrm{a}}$ & $46.6^{\mathrm{a}}$ & $47.6^{\mathrm{b}}$ & 2.13 \\
\hline
\end{tabular}

* Row values within each year with different superscripts differ $(p<0.10 ; n=7)$.

$\dagger$ Standard error of mean. 
Table 5. Chemical composition and digestibility of the major grass species in late-summer grazing season in the Catherine Creek riparian area on the Hall Ranch in northeastern Oregon, USA over 2 years

\begin{tabular}{|c|c|c|c|c|c|}
\hline \multirow[t]{2}{*}{ Forage Species } & \multirow[t]{2}{*}{ Dates } & \multicolumn{2}{|c|}{$\begin{array}{c}\text { Chemical Composition } \\
\text { (\% DM basis })\end{array}$} & \multicolumn{2}{|c|}{ Digestibility (\%) } \\
\hline & & $\mathrm{CP}$ & $\mathrm{NDF}$ & IVDMD & IVOMD \\
\hline \multirow[t]{4}{*}{ Redtop } & $\mathrm{d} 0$ & $6.5 \pm 2.0$ & $60.5 \pm 3.0$ & $43.9 \pm 2.6$ & $44.6 \pm 2.5$ \\
\hline & d 10 & $4.8 \pm 0.4$ & $60.7 \pm 1.5$ & $41.6 \pm 1.5$ & $42.1 \pm 1.5$ \\
\hline & $\mathrm{d} 20$ & $4.6 \pm 0.9$ & $60.2 \pm 2.3$ & $42.7 \pm 2.6$ & $43.1 \pm 2.6$ \\
\hline & d 30 & $5.3 \pm 1.2$ & $64.1 \pm 1.9$ & $41.8 \pm 1.2$ & $41.7 \pm 0.8$ \\
\hline \multirow[t]{4}{*}{ Quackgrass } & $\mathrm{d} 0$ & $9.8 \pm 2.8$ & $65.9 \pm 4.7$ & $39.4 \pm 4.5$ & $40.2 \pm 4.4$ \\
\hline & d 10 & $4.6 \pm 0.3$ & $66.3 \pm 1.6$ & $39.3 \pm 2.8$ & $39.6 \pm 3.0$ \\
\hline & $\mathrm{d} 20$ & $4.4 \pm 0.7$ & $65.4 \pm 6.0$ & $38.8 \pm 4.5$ & $39.3 \pm 5.0$ \\
\hline & d 30 & $4.9 \pm 1.1$ & $67.4 \pm 5.7$ & $40.2 \pm 3.8$ & $40.5 \pm 3.8$ \\
\hline \multirow[t]{4}{*}{ California Brome } & $\mathrm{d} 0$ & $9.9 \pm 1.8$ & $76.1 \pm 3.5$ & $37.0 \pm 4.1$ & $36.2 \pm 4.6$ \\
\hline & d 10 & $3.5 \pm 0.2$ & $76.8 \pm 2.3$ & $35.3 \pm 0.4$ & $33.9 \pm 1.1$ \\
\hline & $\mathrm{d} 20$ & $3.9 \pm 1.6$ & $74.6 \pm 4.8$ & $39.0 \pm 4.9$ & $38.1 \pm 4.4$ \\
\hline & d 30 & $4.8 \pm 1.2$ & $72.5 \pm 5.0$ & $40.4 \pm 4.8$ & $39.4 \pm 4.6$ \\
\hline \multirow[t]{4}{*}{ Elk Sedge } & $\mathrm{d} 0$ & $7.4 \pm 0.2$ & $63.4 \pm 0.6$ & $46.4 \pm 0.4$ & $47.0 \pm 0.9$ \\
\hline & d 10 & $7.5 \pm 0.7$ & $62.9 \pm 0.7$ & $48.0 \pm 2.9$ & $48.7 \pm 3.3$ \\
\hline & $\mathrm{d} 20$ & $6.9 \pm 1.1$ & $61.1 \pm 0.3$ & $47.7 \pm 1.8$ & $48.8 \pm 1.7$ \\
\hline & d 30 & $7.3 \pm 1.3$ & $60.7 \pm 0.2$ & $49.6 \pm 2.5$ & $50.8 \pm 2.3$ \\
\hline \multirow[t]{4}{*}{ Western Fescue } & $\mathrm{d} 0$ & $8.4 \pm 2.9$ & $69.5 \pm 0.2$ & $32.2 \pm 0.3$ & $32.6 \pm 0.4$ \\
\hline & d 10 & $5.4 \pm 1.2$ & $68.3 \pm 6.0$ & $35.7 \pm 6.6$ & $36.1 \pm 7.3$ \\
\hline & $\mathrm{d} 20$ & $5.1 \pm 1.9$ & $71.1 \pm 7.9$ & $36.2 \pm 6.2$ & $36.6 \pm 6.9$ \\
\hline & d 30 & $4.6 \pm 1.5$ & $72.1 \pm 9.7$ & $34.6 \pm 8.6$ & $34.9 \pm 9.6$ \\
\hline \multirow[t]{4}{*}{ Timothy } & $\mathrm{d} 0$ & $3.8 \pm 0.8$ & $64.0 \pm 4.3$ & $43.9 \pm 4.1$ & $43.7 \pm 3.9$ \\
\hline & d 10 & $4.2 \pm 0.4$ & $64.0 \pm 0.7$ & $42.9 \pm 2.6$ & $42.7 \pm 2.8$ \\
\hline & $\mathrm{d} 20$ & $3.8 \pm 0.2$ & $62.7 \pm 5.2$ & $44.7 \pm 2.5$ & $44.4 \pm 2.8$ \\
\hline & d 30 & $5.4 \pm 0.3$ & $64.5 \pm 4.4$ & $44.8 \pm 6.6$ & $44.4 \pm 7.1$ \\
\hline \multirow[t]{4}{*}{ Kentucky Bluegrass } & $\mathrm{d} 0$ & $6.5 \pm 1.8$ & $64.1 \pm 0.5$ & $45.9 \pm 0.8$ & $46.5 \pm 1.4$ \\
\hline & $\mathrm{d} 10$ & $7.0 \pm 1.7$ & $65.5 \pm 3.5$ & $48.5 \pm 4.2$ & $48.6 \pm 4.3$ \\
\hline & $\mathrm{d} 20$ & $6.2 \pm 1.5$ & $65.1 \pm 3.7$ & $47.6 \pm 4.2$ & $48.4 \pm 4.7$ \\
\hline & d 30 & $9.1 \pm 3.8$ & $66.2 \pm 1.8$ & $47.4 \pm 6.7$ & $47.7 \pm 6.3$ \\
\hline
\end{tabular}

\subsection{Forage Quality}

No interactions were detected on nutritive quality of these forages by sampling dates $(p>0.10)$. Our study indicated that forbs and shrubs in the pasture did not vary in nutritive quality $(p>0.10)$ throughout the grazing season and contained relatively high CP averaged at 10.8 and $13.7 \%$, respectively (Table 4). In contrast, grasses were lower in CP averaged at 5.9\% with a notable decline on $\mathrm{d} 20(p<0.10)$. Forbs were mostly higher $(p<0.10)$ in NDF and digestibility than shrubs. Likewise, Holechek and Vavra (1983) and Damiran, DelCurto, Findholt, Johnson, and Vavra (2013) have reported the higher crude protein content and less total fiber of forbs and shrubs compared to grasses. Our data confirm those found elsewhere in that crude protein levels rapidly decline in the dominant grasses of the interior Pacific Northwest and northern Great Basin as they enter reproductive phenological stages, and by July drop below 7.5\% and continue to decline through summer and fall (Ganskopp \& Bohnert, 2001; Clark, 2003). The CP content in grass and grasslike species ranged from 3.8 to $9.9 \%$ on $\mathrm{d} 0$ 
and 3.5 to $9.1 \%$ on d 30 (Table 5). Western fescue, quackgrass, and California brome appeared to decline in CP earlier, at $\mathrm{d} 0$ to $\mathrm{d} 10$. Regrowth was observed in Kentucky bluegrass and timothy later in the grazing period in Year 2, which likely resulted in the CP increases obtained for these species by d 30 . In contrast to the grasses, elk sedge (Carex geyeri Boott) was characterized by a relatively stable $\mathrm{CP}$ level, averaging at $7.3 \%$ throughout the grazing season. Our findings were in agreement with Skovlin (1967) who noted that elk sedge maintained its crude protein content later in the grazing season and showed less seasonal and annual variations as compared to grasses. Also, Clark (2003) found that while CP in dominant grasses typically drops below $7.5 \%$ and continues to decline, crude protein in elk sedge from the Blue Mountains of Oregon remains above this level at least through mid-July, providing a maintenance diet later into the season. In our study, red clover had the highest CP content $(16.8 \% \mathrm{CP}$ ) with other forbs' $\mathrm{CP}$ ranging from 8.1 to $9.6 \%$ (Table 6 ).

Table 6. Chemical composition and digestibility of forbs and shrubs in late-summer grazing season in the Catherine Creek riparian area on the Hall Ranch in northeastern Oregon USA

\begin{tabular}{ccccc}
\hline Dates & \multicolumn{2}{c}{ Chemical Composition* (\% DM basis) } & \multicolumn{2}{c}{ Digestibility (\%) } \\
& CP & NDF & IVDMD & IVOMD \\
\hline Forbs & & 36.6 & 57.1 & 54.8 \\
d 0 & 11 & 33.2 & 59.9 & 57.7 \\
d 10 & 11.1 & 36.1 & 56.9 & 54.7 \\
d 20 & 10.7 & 34.9 & 60 & 57.4 \\
d 30 & 10.3 & 2.66 & 2.73 & 2.82 \\
se $\dagger$ & 1.24 & & & \\
Shrubs & & 29.6 & 51.7 & 48.9 \\
d 0 & 13.9 & 27.9 & 51.6 & 49 \\
d 10 & 14.2 & 31.7 & 47.4 & 44.7 \\
d 20 & 13.6 & 30.3 & 47.2 & 44.3 \\
d 30 & 13 & 3.12 & 3.14 & 3.34 \\
se & 1.31 & \multicolumn{4}{c}{} \\
\hline within each forage with different superscripts differ $(p<0.10 ; n=8$ and 6). \\
mean.
\end{tabular}

Overall, NDF content was highest in grasses (66.1\%), intermediate in forbs (35.6\%), and lowest in shrubs (30.0\%). Conversely, forbs had the greatest IVDMD (58.5\%), shrubs were intermediate (49.5\%), and grasses had the lowest $(41.9 \%)$ during the grazing period. Among the forage species, heartleaf arnica was the highest in digestibility (72.3\% IVDMD). With shrubs, thinleaf alder was higher in CP (17.4\%), but lower in digestibility (42.9\% IVDMD) compared to firmleaf willow and common snowberry, which averaged 13.7 and $10.0 \% \mathrm{CP}$, respectively and similar IVDMD averaged $52.9 \%$ (Table 6).

These findings generally concurred with Parsons et al. (2003), who found higher NDF (68.4\%) and lower CP (4.5\%) in late-season forage (mid-August to mid-September) as compared to early-season forage on riparian pastures in northeastern Oregon. Results on forage quality in our study also revealed that during the latesummer grazing period nutritive quality of grasses were below animal requirements as opposed to other forages. Our results support Vavra (1983) who has stated that forage quality on northeastern Oregon forested rangelands decline below required levels by late-August, while shrubs contain higher levels of crude protein later in the grazing season than herbaceous species.

\subsection{Shrub Utilization}

Shrub utilization measured on two common shrub species in the area, thinleaf alder and firmleaf willow, indicated that as the grazing season progressed cattle browsing activity intensified (Figure 3). Thus, the use of both species by cattle increased $(p<0.10)$ throughout the grazing period with an exception of the last 10-days for willow $(p>0.10)$. The data showed that in the riparian pasture cattle browsing activity estimated by $\mathrm{d} 20$ (mid-August) was $49.2 \%$ on willow and $57.8 \%$ on alder, and remained higher to the end of the trial, accounted 
for 57.5 and $74.1 \%$, respectively for these shrub species $(p<0.10)$. Shrubs add desired variety to the cattle diet and because of their scarcity are rather heavily utilized by game and livestock, as implied by Pickford and Reid (1948). Willow utilization, as estimated by Kauffman et al. (1983a) in the same area, ranged from 27 to $48 \%$, whereas Smith et al. (1992) have observed as much as 57\% use. Also, Roath \& Krueger (1982) recorded 37\% willow and $47 \%$ alder use in the early-season grazing and noted that willow was utilized in excess of its percentage availability. The increase in shrub use by cattle observed in our study was likely influenced also, by drought conditions in the summers and, as a result, low succulence, quality, and palatability of herbaceous forages. In the same way observed Vavra (1983) and Ballard and Krueger (2005) during the late-grazing period and Roath and Krueger (1982) during the early season, which they related to the year of low precipitation or low herbaceous production, and also, in response to rapidly advancing herbaceous vegetation maturity and it becoming less palatable (Damiran, 2005) and/or declining in availability with cattle grazing riparian areas. In addition, Holechek et al. (1982) reported that on the forested rangelands, in the latter half of the grazing season, cattle responded to weather conditions by shifting their diets away from grasses to browse when green regrowth due to summer precipitation, was not available. Lower utilization of shrubs observed during the first 10 days ( $p<$ 0.10 ) of our trials could be attributed to that the grasses initially had relatively good quality and succulence. Overall, there was heavier use on alder than willow $(p<0.10)$, nearly $17 \%$ higher, at the end of the grazing season, which may be due to alder being higher in CP (17.4\% vs. $13.7 \%)$, and more abundant and evenly distributed in the area relative to willow. Lower density of willow species in grazed areas was noted compared to areas where grazing was excluded, according to the studies in the same area (Kauffman et al., 1983a; Green \& Kauffman, 1995).

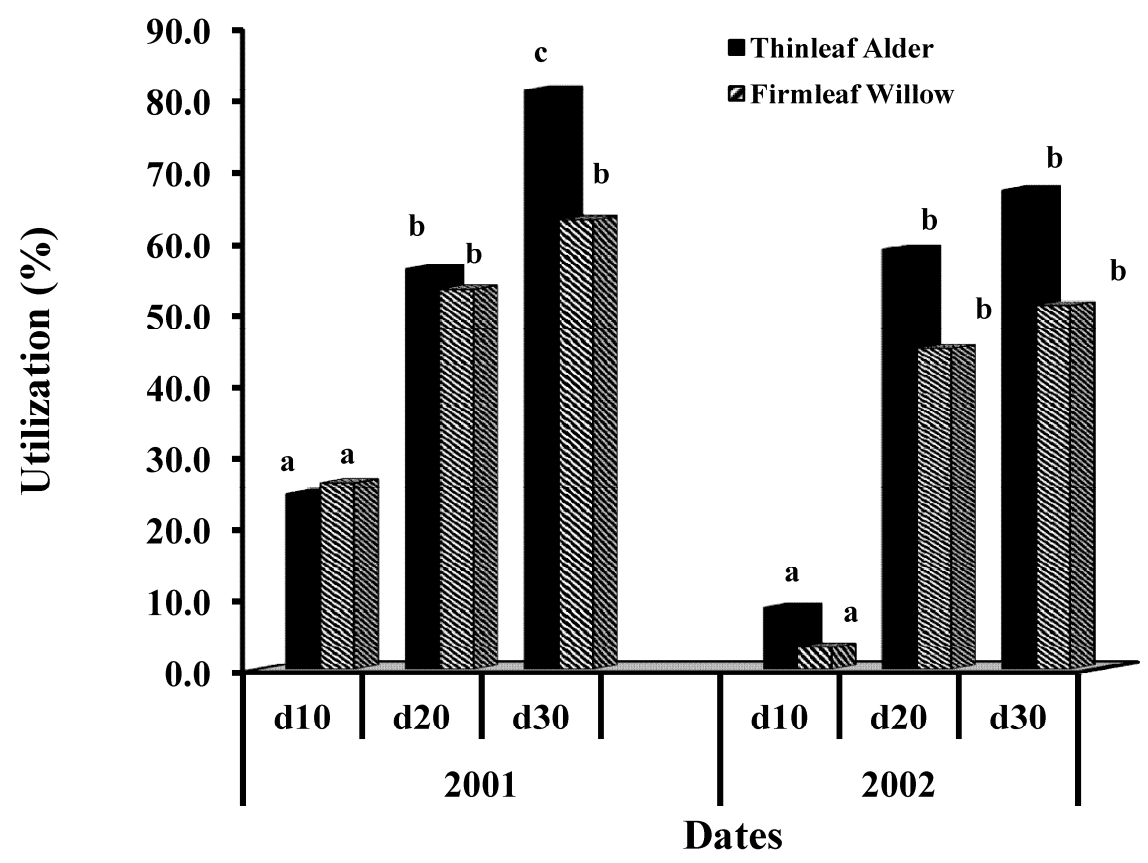

Figure 3. Shrub utilization (\%) in late-summer grazing season in the Catherine Creek riparian area on the Hall Ranch in northeastern Oregon, USA for 2001 and 2002 (Values within each year and date with different superscripts differ. $p<0.05$; $\mathrm{se}=6.45 ; n=16$ )

The Catherine Creek site used in this study has been evaluated extensively by other researchers and reflects $>25$ years of late-summer grazing (Darambazar, 2003). This grazing approach has not significantly impacted riparian vegetation when evaluated across plant communities, although some influences within plant communities have occurred with structural diversity of woody plant communities being affected (Kauffman et al., 1983a, 1983b; Green \& Kauffman, 1995). Previous studies suggest both grazed and ungrazed sites in the Catherine Creek area are improving relative to 1978. Nevertheless, our findings demonstrated that cattle grazing the riparian pasture in the summer during drought conditions could result in significant removal of herbaceous as well as intensive use of woody vegetation. 
Table 7. Chemical composition and digestibility of the major forb and shrub species in late-summer grazing season in the Catherine Creek riparian area on the Hall Ranch in northeastern Oregon USA over 2 years

\begin{tabular}{|c|c|c|c|c|c|}
\hline \multirow[t]{2}{*}{ Forage Species } & \multirow[t]{2}{*}{ Dates } & \multicolumn{2}{|c|}{ Chemical Composition (\% DM) } & \multicolumn{2}{|c|}{ Digestibility (\%) } \\
\hline & & & & IVDMD & IVOMD \\
\hline \multicolumn{6}{|l|}{ Forbs } \\
\hline \multirow[t]{4}{*}{ Western Yarrow } & $\mathrm{d} 0$ & $7.6 \pm 1.5$ & $52.9 \pm 3.9$ & $45.0 \pm 8.1$ & $42.6 \pm 8.8$ \\
\hline & $\mathrm{d} 10$ & $8.6 \pm 0.7$ & $44.9 \pm 6.2$ & $53.9 \pm 6.4$ & $51.9 \pm 7.3$ \\
\hline & $\mathrm{d} 20$ & $8.1 \pm 0.4$ & $43.5 \pm 1.2$ & $54.9 \pm 0.5$ & $53.4 \pm 0.8$ \\
\hline & d 30 & $8.0 \pm 2.2$ & $47.8 \pm 4.3$ & $54.4 \pm 6.2$ & $51.7 \pm 6.0$ \\
\hline \multirow[t]{4}{*}{ Heartleaf Arnica } & $\mathrm{d} 0$ & $9.0 \pm 0.6$ & $25.4 \pm 1.2$ & $72.0 \pm 0.7$ & $70.2 \pm 0.5$ \\
\hline & $\mathrm{d} 10$ & $8.7 \pm 0.1$ & $25.1 \pm 0.3$ & $74.0 \pm 1.4$ & $72.5 \pm 1.7$ \\
\hline & $\mathrm{d} 20$ & $9.1 \pm 0.3$ & $26.8 \pm 3.1$ & $69.4 \pm 4.2$ & $67.8 \pm 4.7$ \\
\hline & d 30 & $8.2 \pm 0.2$ & $24.8 \pm 0.2$ & $73.8 \pm 1.8$ & $72.1 \pm 1.6$ \\
\hline \multirow[t]{4}{*}{ Strawberries * } & $\mathrm{d} 0$ & $10.2 \pm 0.7$ & $28.8 \pm 4.1$ & $50.9 \pm 0.3$ & $48.5 \pm 0.4$ \\
\hline & $\mathrm{d} 10$ & $8.8 \pm 0.3$ & $28.1 \pm 2.9$ & $50.3 \pm 0.7$ & $48.0 \pm 0.6$ \\
\hline & $\mathrm{d} 20$ & $9.8 \pm 0.7$ & $31.9 \pm 3.2$ & $48.0 \pm 1.6$ & $45.5 \pm 1.8$ \\
\hline & d 30 & $9.5 \pm 0.9$ & $25.6 \pm 2.8$ & $52.3 \pm 1.6$ & $49.6 \pm 2.3$ \\
\hline \multirow[t]{4}{*}{ Red Clover } & $\mathrm{d} 0$ & $17.2 \pm 1.4$ & $39.3 \pm 5.1$ & $60.4 \pm 3.7$ & $57.8 \pm 3.7$ \\
\hline & $\mathrm{d} 10$ & $18.5 \pm 1.7$ & $34.6 \pm 2.6$ & $61.4 \pm 0.1$ & $58.6 \pm 0.2$ \\
\hline & $\mathrm{d} 20$ & $15.8 \pm 0.3$ & $42.3 \pm 4.7$ & $55.4 \pm 4.2$ & $52.4 \pm 4.8$ \\
\hline & d 30 & $15.5 \pm 1.5$ & $41.2 \pm 2.3$ & $59.4 \pm 2.6$ & $56.3 \pm 2.6$ \\
\hline \multicolumn{6}{|l|}{ Shrubs } \\
\hline \multirow[t]{4}{*}{ Thinleaf Alder } & $\mathrm{d} 0$ & $18.3 \pm 2.2$ & $34.3 \pm 2.4$ & $43.1 \pm 0.7$ & $40.5 \pm 0.4$ \\
\hline & $\mathrm{d} 10$ & $17.9 \pm 0.2$ & $32.4 \pm 0.5$ & $46.9 \pm 2.4$ & $44.6 \pm 2.7$ \\
\hline & $\mathrm{d} 20$ & $17.0 \pm 0.7$ & $38.0 \pm 3.2$ & $39.3 \pm 5.3$ & $36.7 \pm 5.9$ \\
\hline & $\mathrm{d} 30$ & $16.3 \pm 2.4$ & $35.5 \pm 1.5$ & $42.3 \pm 0.1$ & $39.6 \pm 0.2$ \\
\hline \multirow[t]{4}{*}{ Firmleaf Willow } & $\mathrm{d} 0$ & $13.2 \pm 1.1$ & $28.5 \pm 0.6$ & $57.6 \pm 1.2$ & $54.9 \pm 1.7$ \\
\hline & $\mathrm{d} 10$ & $14.3 \pm 0.2$ & $23.1 \pm 1.4$ & $53.7 \pm 2.1$ & $51.0 \pm 2.3$ \\
\hline & $\mathrm{d} 20$ & $14.3 \pm 0.5$ & $27.4 \pm 1.4$ & $51.4 \pm 3.9$ & $48.9 \pm 2.8$ \\
\hline & $\mathrm{d} 30$ & $13.1 \pm 1.2$ & $26.4 \pm 4.9$ & $48.5 \pm 3.2$ & $45.5 \pm 3.1$ \\
\hline \multirow[t]{4}{*}{ Common Snowberry } & $\mathrm{d} 0$ & $10.3 \pm 1.9$ & $26.2 \pm 2.5$ & $54.4 \pm 5.4$ & $51.2 \pm 6.3$ \\
\hline & $\mathrm{d} 10$ & $10.3 \pm 1.1$ & $28.2 \pm 2.9$ & $54.4 \pm 1.4$ & $51.3 \pm 1.5$ \\
\hline & $\mathrm{d} 20$ & $9.5 \pm 0.1$ & $29.8 \pm 5.1$ & $51.7 \pm 2.4$ & $48.4 \pm 3.1$ \\
\hline & d 30 & $9.7 \pm 1.3$ & $29.1 \pm 3.3$ & $51.0 \pm 0.1$ & $47.8 \pm 0.3$ \\
\hline
\end{tabular}

* Strawberries included two species: blueleaf strawberry and woods strawberry.

\section{Conclusions}

Our data revealed that maturation and drying of grasses and consequent decline in the quality can occur as early as in the first half of the late-summer grazing in riparian pastures. While forbs and shrubs remain higher in quality, the availability of forbs decline considerably in late summer. This would suggest that in response to changes in the quantity and quality of grasses and availability of forbs, cattle grazing late-summer riparian pastures will switch to intensive shrub utilization. Since many larger meadows in northeastern Oregon and western North America are similar to the meadow at Catherine Creek, our findings would be useful in 
monitoring riparian (watershed) area use and evaluating management strategies. Land managers need to know the effect of their management on vegetation and if a goal is to protect riparian woody vegetation, our data suggest that late-summer grazing should be light, or avoided when grasses have senesced. In addition, further investigation on foraging habits of cattle grazing riparian pastures in relation to forage availability and quality is needed.

\section{Acknowledgments}

This research was funded by the Eastern Oregon Agricultural Research Center, Union, Oregon. We thank Uranbileg Daalkhaijav and Amartuvshin Daalkhaijav for assistance with field work; also thank to Drs. G. D. Pulsipher, and D. E. Johnson of Oregon State University USA, and Dr HA (Bart) Lardner of University of Saskatchewan Canada for their comments on this manuscript.

\section{References}

AOAC (Association of Official Analytical Chemists). (1990). Official methods of analysis (15th ed.). Arlington, VA. USA.

Ballard, T. M., \& Krueger, W. C. (2005). Cattle and salmon I: Cattle distribution and behavior in a northeastern Oregon riparian ecosystem. Journal of Range Management, 58, 267-273. http://dx.doi.org/10.2111/1551-5028(2005)58[267:CASICD]2.0.CO;2

Buckhouse, J. C., Skovlin, J. M., \& Knight, R. W. (1981). Streambank erosion and ungulate grazing relationships. Journal of Range Management, 34, 339-340. http://dx.doi.org/10.2307/3897866

Clark, P. E. (2003). Date and plant community effects on elk sedge forage quality. Journal of Range Management, 56, 21-26. http://dx.doi.org/10.2307/4003876

Damiran, D. (2005). Palatability of Mongolian rangeland plants. Circular of information No.3. Union, Oregon, USA: Oregon State University, Eastern Oregon Agricultural Research Station. Oregon, USA.

Damiran, D., DelCurto, T., Findholt, S., Johnson, B., \& Vavra, M. (2013). Comparison of bite-count and rumen evacuation techniques to estimate diet quantity and quality in grazing cattle. Rangeland Ecology and Management, 66, 106-109. http://dx.doi.org/10.2111/REM-D-12-00046.1

Damiran, D., DelCurto, T., Johnson, D. E. Findholt, S. L., \& Johnson, B. K. (2006). Estimating shrub forage yield and utilization using a photographic technique. Northwest Science, 80, 259-263. http://www.vetmed.wsu.edu/org_nws/NWSci\%20journal\%20articles/2006\%20files/Issue\%204/03\%20Dam iran.pdf

Darambazar, E. (2003). Factors influencing diet composition of beef cattle grazing mixed conifer mountain riparian areas. M.S. thesis. Oregon State University, Corvallis, OR, USA.

DelCurto, T., Cochran, R. C., Corah, L. R., Beharka, A. A., Vanzant, E. S., \& Johnson, D. E. (1990). Supplementation of dormant tallgrass-prairie forage: II. Performance and forage utilization characteristics in grazing beef cattle receiving supplements of different protein concentrations. Journal of Animal Science, 68, 532-542. http://www.journalofanimalscience.org/content/68/2/532

DelCurto, T., Porath, M., Parsons, C. T., \& Morrison, J. A. (2005). Management strategies for sustainable beef cattle grazing on forested rangelands in the Pacific Northwest. Invited synthesis paper. Journal of Range Management, 58, 119-127. http://dx.doi.org/10.2111/1551-5028(2005)58<119:MSFSBC $>2.0 . C O ; 2$

Ganskopp, D., \& Bohnert, D. (2001). Nutritional dynamics of 7 northern Great Basin grasses. Journal of Range Management, 54, 640-647. http://dx.doi.org/10.2307/4003664

Gillen, R., Krueger, W. C., \& Miller, R. (1985). Cattle use of riparian meadows in the Blue Mountains of northeastern Oregon. Journal of Range Management, 38, 205-209. http://dx.doi.org/10.2307/3898967

Green, D. M., \& Kauffman, J. B. (1995). Succession and livestock grazing in a northeastern Oregon riparian ecosystem. Journal of Range Management, 48, 307-313. http://dx.doi.org/10.2307/4002482

Hitchcock, C. L., Cronquist, A., Ownbey, M., \& Thompson, J. W. (1966). Vascular plants of the Pacific Northwest. Univ. Wash. Pub. In Biol., Vol. 17, Seattle, WA: University of Washington Press.

Holechek, J. L., \& Vavra, M. (1983). Drought effects on diet and weight gains of yearling heifers in northeastern Oregon. Journal of Range Management, 36, 227-231. http://dx.doi.org/10.2307/3898169

Holechek, J. L., Vavra, M., Skovlin, J., \& Krueger, W. C. (1982). Cattle diets in the Blue Mountains of Oregon II. Forests. Journal of Range Management, 35, 239-242. http://dx.doi.org/10.2307/3898400 
Hurd, R. M., \& Pond F. W. (1958). Relative preference and productivity of species on summer cattle ranges, Big Horn Mountains. Wyoming. Journal of Range Management, 11, 109-114. http://dx.doi.org/10.2307/3893710

Kauffman, J. B., Krueger, W. C., \& Vavra, M. (1983a). Effects of late season cattle grazing on riparian plant communities. Journal of Range Management, 36, 685-691. http://dx.doi.org/10.2307/3898185

Kauffman, J. B., Krueger, W. C., \& Vavra, M. (1983b). Impacts of cattle on stream banks in northeastern Oregon. Journal of Range Management, 36, 683-685. ttp://dx.doi.org/10.2307/3898184

Laliberte, A., Johnson, D. E., Harris, N., \& Casady, G. (2001). Stream change analysis using remote sensing and Geographic Information Systems (GIS). Journal of Range Management, 54, 22-50.

Leege, T. A., Herman, D. J., \& Zamora, B. (1981). Effects of cattle grazing on mountain meadows in Idaho. Journal of Range Management, 34, 324-328. http://dx.doi.org/10.2307/3897861

Parsons, C. T., Momont, P. A., DelCurto, T., McInnis, M., Porath, M. L. (2003). Cattle distribution patterns and vegetation use in mountain riparian areas. Journal of Range Management, 56, 334-341. http://dx.doi.org/10.2307/4004036

Pickford, G. D., \& Reid, E. H. (1948). Forage utilization on summer cattle ranges in eastern Oregon. U. S. Dept. Agric. Circ. 796., Washington, DC: U. S. Government Printing Office.

Porath, M. L., Momont, P. A., DelCurto, T., Rimbey, N. R., Tanaka, J. A., \& McInnis, M. (2002). Offstream water and trace mineral salt as management strategies for improved cattle distribution. Journal of Animal Science, 80, 346-356.

Reid, E. H., \& Pickford, G. D. (1946). Judging mountain meadow range condition in eastern Oregon and eastern Washington. U. S. Dept. Agric. Circ. 748. U. S. Washington, DC: U. S. Government Printing Office.

Roath, L. R., \& Krueger, W. C. (1982). Cattle grazing and behavior on a forested range. Journal of Range Management, 35, 332-338. http://dx.doi.org/10.2307/3898312

SAS Institute Inc. (2001). SAS/STAT User's Guide, Release 8.2. SAS Institute Inc., Cary, N.C. USA.

Skovlin, J. M. (1967). Fluctuations in forage quality on summer range in the Blue Mountains. U. S. Department of Agriculture, Pacific Northwest, Pacific Northwest Forest and Range Experiment Station 44, USA.

Smith, M. A., Rodgers, J. D., Dodd, J. L. \& Skinner, Q. D. (1992). Declining forage availability effects on utilization and community selection by cattle. Journal of Range Management, 45, 391-395. http://dx.doi.org/10.2307/4003089

Stoddart, L., Smith, A., \& Box, T. (1975). Range management (3rd ed.). New York, NY: McGraw-Hill.

Svejcar, T., \&Vavra, M. (1985). The influence of several range improvements on estimated carrying capacity and potential beef production. Journal of Range Management, 38, 395-399. http://dx.doi.org/10.2307/3899706

Tilley, J. M. A., \& Terry, R. A. (1963). A two-stage technique for the in vitro digestion of forage crops. Journal of British Grassland Society, 18, 104-111. ttp://dx.doi.org/10.1111/j.1365-2494.1963.tb00335.x

Van Soest, P. J., Robertson, J. B., \& Lewis, B. A. (1991). Methods for Dietary Fiber, Neutral Detergent Fiber, and Nonstarch Polysaccharides in Relation to Animal Nutrition. Journal of Dairy Science, 74, 3583-3597. http://dx.doi.org/10.3168/jds.S0022-0302(91)78551-2

Vavra, M. (1983). Managing grazing animal response to forestland vegetation. In B. F. Roche, Jr., \& D. M. Baumgartner (Eds.), Proceedings of Symposium Forestland Grazing (pp. 43-51). 23-25 February 1983; Spokane, WA. Pullman, WA: Washington State University. USA. http://oregonstate.edu/dept/eoarc/sites/default/files/publication/292.pdf

\section{Copyrights}

Copyright for this article is retained by the author(s), with first publication rights granted to the journal.

This is an open-access article distributed under the terms and conditions of the Creative Commons Attribution license (http://creativecommons.org/licenses/by/3.0/). 